\title{
Sauna Technique, Drying Kinetic Modeling and Effectiveness on Solar Drying Compared with Direct Drying in Drying Process of Kappaphycus striatum in Selakan Island Malaysia
}

\author{
Majid Khan Majahar Ali' ${ }^{*}$, Ahmad Fudholi2 , Jumat Sulaiman1, Mohd Hafidz Ruslan², \\ Suhaimi Md. Yasir ${ }^{3 *}$ \\ ${ }^{1}$ Mathematics with Economics Programme, School of Science and Technology, University Malaysia Sabah, \\ Kota Kinabalu, Sabah, Malaysia \\ ${ }^{2}$ Solar Energy Research Institute (SERI), Universiti Kebangsaan Malaysia, Bangi, Selangor, Malaysia \\ ${ }^{3}$ Seaweed Research Unit (UPRL), School of Science and Technology, University Malaysia Sabah, \\ Kota Kinabalu, Sabah, Malaysia \\ Email: * $\underline{\text { majidkhankhan@ymail.com, }}$ * suhaimi.yasir@gmail.com
}

Received 29 June 2014; revised 20 July 2014; accepted 5 August 2014

Copyright (C 2014 by authors and Scientific Research Publishing Inc.

This work is licensed under the Creative Commons Attribution International License (CC BY).

http://creativecommons.org/licenses/by/4.0/

(c) (i) Open Access

\begin{abstract}
A sauna drying technique-the solar drier was designed and imposed, constructed and tested for drying of seaweed. The seaweed moisture content was decreased around $50 \%$ in 2 -day sauna. Kinetic curves of drying of seaweed were known to be used in this system. The non-linear regression procedure was used to fit three different drying models. The models were compared with experimental data of red seaweed being dried on the daily average of air temperature about $40^{\circ} \mathrm{C}$. The fit quality of the models was evaluated using the coefficient of determination $\left(R^{2}\right)$, Mean Bias Error (MBE) and Root Mean Square Error (RMSE). The highest values of $R^{2}(0.99027)$, the lowest MBE (0.00044) and RMSE (0.03039) indicated that the Page model was the best mathematical model to describe the drying behavior of sauna dried seaweed. The percentage of the saved time using this technique was calculated at $57.9 \%$ on the average solar radiation of about $500 \mathrm{~W} / \mathrm{m}^{2}$ and air flow rate of $0.056 \mathrm{~kg} / \mathrm{s}$.
\end{abstract}

\section{Keywords}

Mathematical Modeling, Sauna Technique, Drying Curve, Moisture Content, Seaweed,

"Corresponding author.

How to cite this paper: Ali, M.K.M., Fudholi, A., Sulaiman, J., Ruslan, M.H. and Yasir, S.Md. (2014) Sauna Technique, Drying Kinetic Modeling and Effectiveness on Solar Drying Compared with Direct Drying in Drying Process of Kappaphycus striatum in Selakan Island Malaysia. Energy and Power Engineering, 6, 303-315. http://dx.doi.org/10.4236/epe.2014.69026 


\section{Kappaphycus striatum}

\section{Introduction}

Seaweed has been given much more concern because of its high nutritional value [1] and its short-term growth that is only 45 days per cycle [2]. Seaweed is mainly cultivated in Sabah due to its suitability like environmental and geographical factors compared with peninsular Malaysia [3]. In addition, Malaysia lies entirely in the equatorial region. On average, Malaysia receives 4.21 to $5.56 \mathrm{kWh} / \mathrm{m}^{2}$ of solar radiation a year. ETP focus is mainly to transform the system in seaweed to make it one of the industries, which is also competitive, standardized and independent like other agriculture sectors [4]. It also will provide a lot of job opportunities for the people in Sabah, decrease the poverty of pupils especially in west coast of Sabah and increase of farmers' household income. Moreover, it also will attract investors to come and invest in our country.

According to [5], the main extraction from seaweed is because of its carrageenan. The carrageenan is used in human food and non-food, pet food, cosmetics, meat binders and etc. [6]. East ASEAN Growth Area (BIMPEAGA) mentions that the world demand of carrageenan from seaweed will increase to $80 \%$ by the year 2020 . Traditionally seaweed is dried in open sunlight. Drying of seaweed by using hanging method in an open area or on a wooden platform depends on the weather, large open space areas and long drying time and has low product quality and other contaminations [7]. The weaknesses of direct drying affect the income of the farmers and make the payment delay [8]. It is necessary that the period of drying be decreased without affecting the quality of the seaweed [9].

Several experimental and theoretical studies have been reported on the development of various types of solar drying system for agricultural and marine products [10]. Recently, many researches on experimental studies and mathematical modeling have been widely and effectively used for analysis [11]-[16]. Although many mathematical models have been proposed to describe the drying process, a limited number of reported studies are on mathematical models of drying behaviors of seaweed and it seems that no work is done to do sauna on seaweed as pre-treatment to decrease the period of drying without affecting the quality of the carrageenan.

This study is conducted to explain novelty of the sauna process, to propose thin layer solar drier model of seaweed after sauna process (Kappaphyccus striatum variety Sacol) under climatic condition of Malaysia and compare the drying period with traditionally drying.

\section{Material and Methods}

\subsection{Material}

The seaweed (Kappaphyccus striatum variety Sacol) used in this study was obtained from PELADANG association in Semporna, Sabah as shown in Figure 1. The initial moisture content of seaweed was determined by measuring the initial and final weight. Then, it calibrated with oven drying method at the temperature of $115^{\circ} \mathrm{C}$ in order to obtain constant weight. Average initial moisture content obtained was $92.68 \%$ [17].

\subsection{Sauna Technique and Experimental Procedure}

Experiment was done between 8:00 am and 5:00 pm from 19/3/14 until 22/3/14 in Selakan Island, Malaysia. On the 17/3/14, 5 tons fresh seaweed was harvested with the seaweed complete one cycle of cultivation ( 45 days). After determining the initial weight, the fresh seaweed was closed tightly using white anti UV-plastics as shown in Figure 2. This is the sauna process which the seaweed sample will change the color from natural color to the whitish. The next day around afternoon, the plastic opened to flip over the seaweed so that equal formation of the whitish seaweed formed. Then, the plastic was closed tightly again. The seaweed was undergoing the sauna process for 48 hours as shown in Figure 3 and Figure 4. On the second day, the plastic was open and throw away all the water inside plastic and all the sample was wash using sea water went through sauna process. The main objective of sauna is to reduce the moisture content to $50 \%$. The remaining about 2.5 tones after sauna was arranged in the Green V-Roof Hybrid Solar Drier (GVRHSD) with same depth and surface area for the drying process as in Figure 5. On the same day, around 5 tan of fresh seaweed are bought to compare the drying period and effectiveness of sauna technique. 


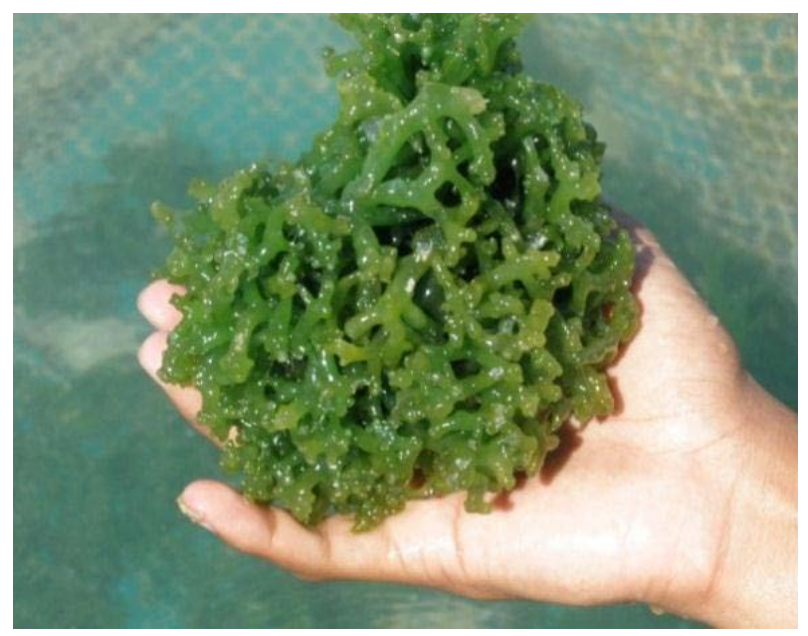

Figure 1. Kappaphycus striatum variety Sacol.

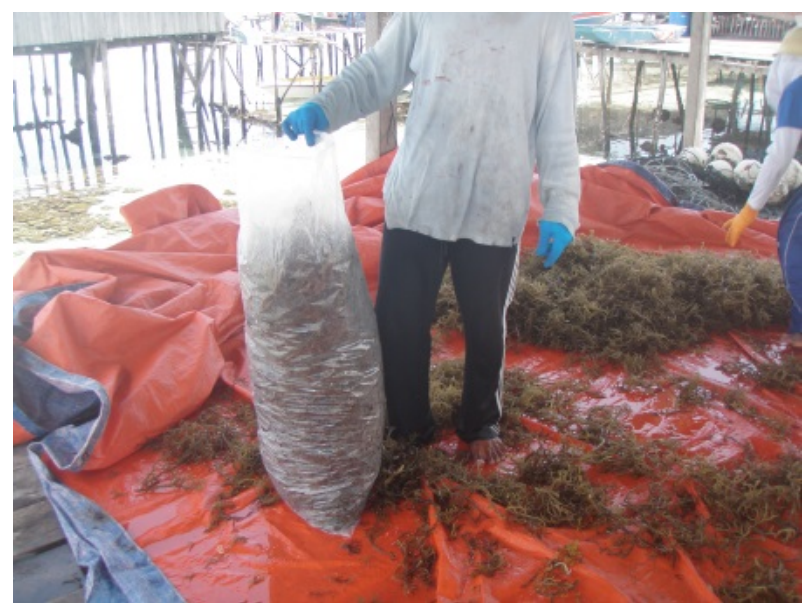

Figure 2. Fresh seaweed put inside the plastics.

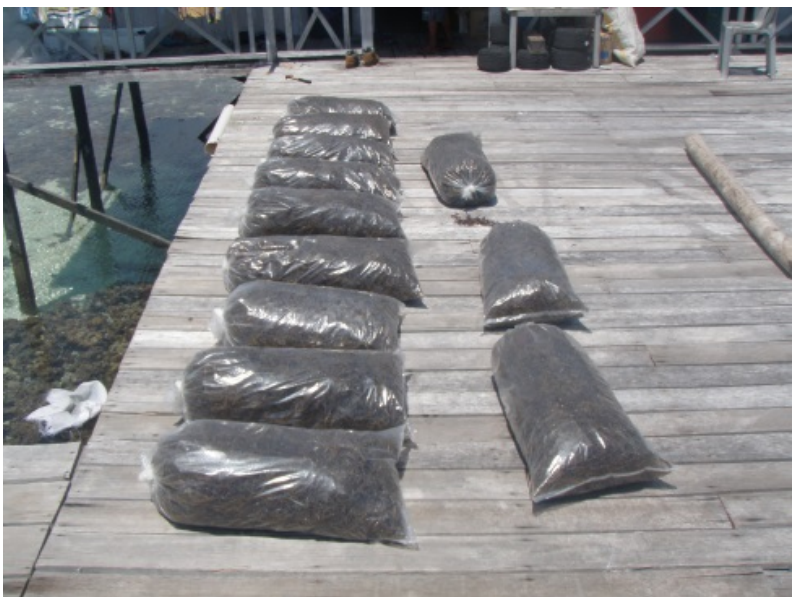

Figure 3. Plastics being dried under the open sun.

Then the tray arranged into the open sun. Number of samples was selected with same amount and put in the different places in the tray. The purpose was to study the drying kinetics in drying time of samples. During the drying experiment, the weather was sunny overall. The data measured include air temperature (ambient temper- 


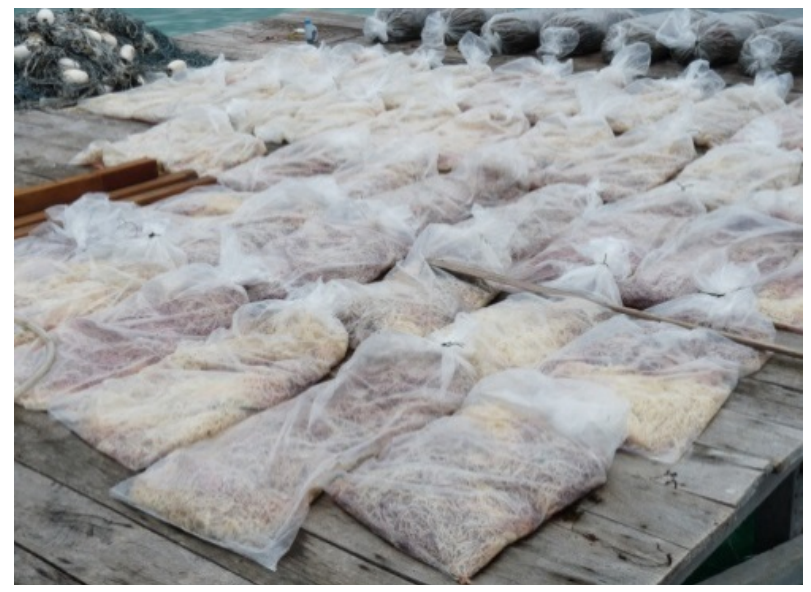

Figure 4. Photograph of sauna seaweed after one day.

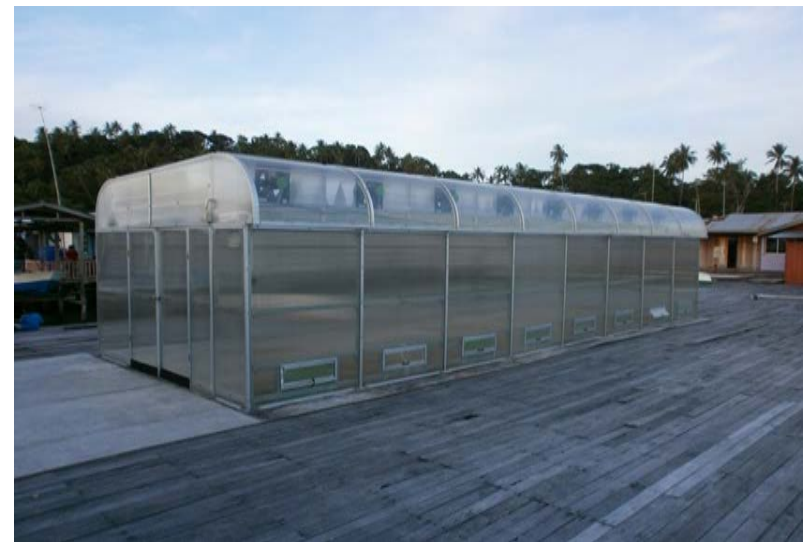

Figure 5. Photograph of sauna seaweed in solar drier.

ature, relative humidity), radiation intensity, and air velocity. For ambient relative humidity and temperature, we used hygrometer. Air temperature was measured by T-type thermocouple, and the intensity of solar radiation was measured using pyranometer. The moisture loss was determined by means of a digital balance which having an accuracy of $0.01 \mathrm{~g}[18]$.

Mathematical modeling of drying curves.

The moisture content was expressed as a percent wet basis. The experimental drying data for red seaweed were fitted to the thin layer drying models in Table 1, the moisture ratio (MR) can be calculated as [19]

$$
M R=\frac{M-M_{e}}{M_{0}-M_{e}}
$$

where,

$M_{e}=$ Equilibrium moisture content;

$M_{0}=$ Initial moisture content;

The moisture content of materials $(M)$ can be calculated by two methods on the basis of either wet or dry basis using the following equation.

The moisture content wet basis [20]

$$
M=\frac{w(t)-d}{w} \times 100 \%
$$

The moisture content dry basis

$$
X=\frac{w(t)-d}{d}
$$


Table 1. Several models of drying [24].

\begin{tabular}{ccc}
\hline No. & Model name & Model \\
\hline 1 & Newton & MR $=\exp (-k t)$ \\
2 & Page & $\mathrm{MR}=\exp \left(-k t^{n}\right)$ \\
3 & Henderson and Pabis & $\mathrm{MR}=a \exp (-k t)$ \\
\hline
\end{tabular}

where,

$w(t)=$ mass of wet materials at instant $t$;

$d=$ mass of dry materials.

The values of the coefficient of determination $\left(R^{2}\right)$, Mean Bias Error (MBE) and Root Mean Square Error (RMSE) were used to determine the quality of the drying model. The highest $R^{2}$ values and the values of MBE and the lowest RMSE were selected to estimate if the drying curve is the best [21] [22].

$$
\begin{gathered}
\mathrm{MBE}=\frac{1}{N} \sum_{i=1}^{N}\left(\mathrm{MR}_{\mathrm{pre}, i}-\mathrm{MR}_{\text {exp }, i}\right)^{2} \\
\mathrm{RMSE}=\left[\frac{1}{N} \sum_{i=1}^{N}\left(\mathrm{MR}_{\mathrm{pre}, i}-\mathrm{MR}_{\text {exp }, i}\right)^{2}\right]^{\frac{1}{2}}
\end{gathered}
$$

Saving Time and Drying Rate [23]

$$
\begin{gathered}
\text { SavingTime }(\mathrm{ST})=\frac{\text { Direct Drying period }- \text { Sauna Drying Period }}{\text { Direct Drying period }} \times 100 \% \\
\text { Drying Rate }(f)=\left(-\frac{\mathrm{d} M}{\mathrm{~d} t}\right)_{t} /\left(\frac{\mathrm{d} M}{\mathrm{~d} t}\right)_{0}
\end{gathered}
$$

\section{Results and Discussion}

During the four days of experiments, the variations of the solar radiation (S), ambient temperature (Ta), and average relative humidity of ambient (Ha) are shown in Figure 6 and Figure 7. From these figures, the daily mean of the drying air temperature, relative humidity of drying and solar radiation range from about $35^{\circ} \mathrm{C}-40^{\circ} \mathrm{C}, 32 \%$ $-80 \%, 100-1100 \mathrm{~W} / \mathrm{m}^{2}$, respectively. During the 4-day drying, the daily averages of relative humidity at the drying were obtained in range $43 \%$ to $45 \%$.

About $2500 \mathrm{~kg}$ of sauna seaweed and $5000 \mathrm{~kg}$ of fresh seaweed are being dried under the sun, drying of sauna seaweed takes two days to reduce the initial moisture content of $96.28 \%$ to $35 \%$, equivalent to $2500 \mathrm{~kg}$ to 281.5 $\mathrm{kg}$ while drying sauna directly will consume about 4 days to produce the dried seaweed about $560.3 \mathrm{~kg}$ from fresh of $5000 \mathrm{~kg}$ seaweed. During the two days drying for sauna, the daily averages of air temperature at the drying platform were $45^{\circ} \mathrm{C}$ and $50^{\circ} \mathrm{C}$ and average solar radiations 453 and $562 \mathrm{~W} / \mathrm{m}^{2}$ at mass flow rate 0.0536 $\mathrm{kg} / \mathrm{s}$, as shown in Figure 6 and Figure 7. The efficiency of saving time about 22 hour using the sauna technique is with the percentage of $57.9 \%$, as shown in Figure 8 and Figure 9.

The kinetic curve of both the drying technique was studied. The sauna and direct drying at two conditions were decreased moisture content and drying as shown in Figure 10. Drying curve for both of the technique can also show the profile change in moisture content $(X)$ versus drying time $(t)$, as shown in Figure 11 and Figure 12. The drying kinetics for both of the technique can be accurately predicted using Newton's model, logarithmic model and Henderson and Pabis model (Gupta et al. [25]). Azoubel et al. [26] reported that Page model clearly improved the simulation in comparison with the results obtained using the diffusion model, having the best fit to the experimental data, with calculated average error ranging from $1.89 \%$ to $12.76 \%$ and $R^{2}$ values greater than 0.99. Page model has shown a better fit than other models at accurately simulate the drying curves of chili pepper [27], rapeseed [28], green beans [29], okra [30], kiwi [31] among others.

Page's equation can also be written to the equation

$$
\ln (-\ln \mathrm{MR})=\ln k+n \ln t
$$




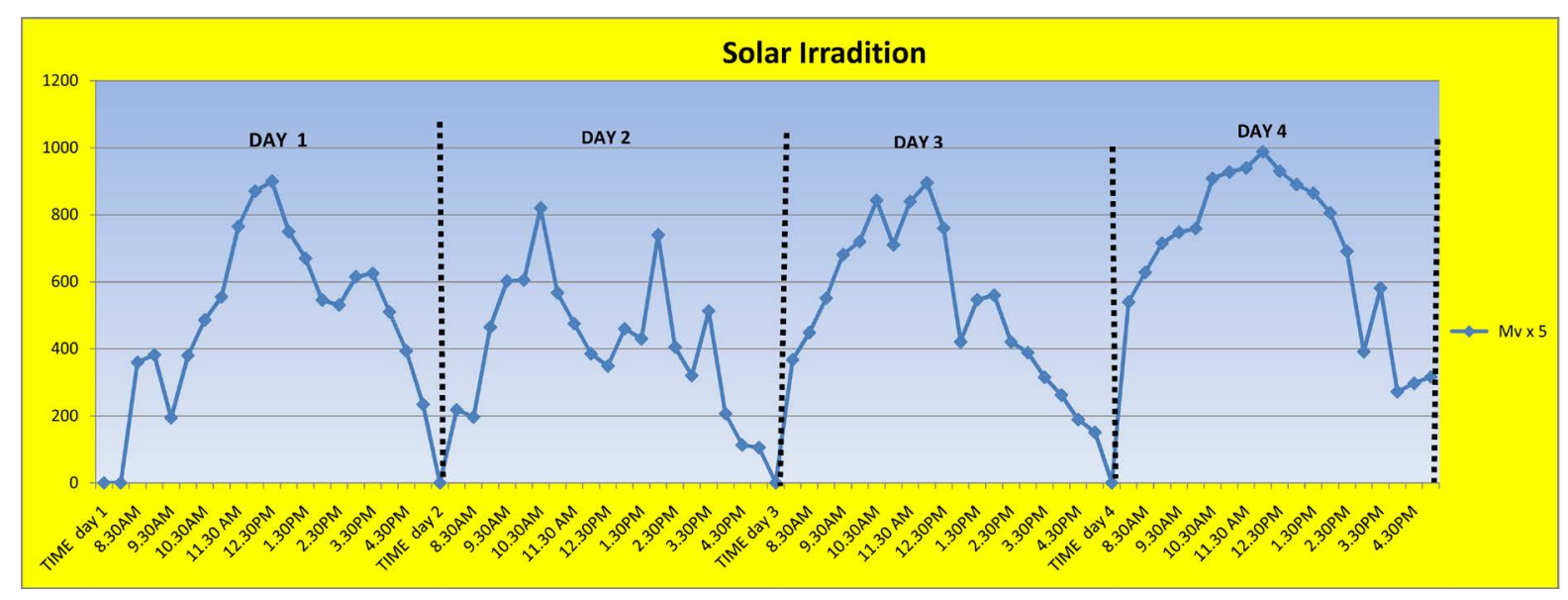

Figure 6. Solar radiation.

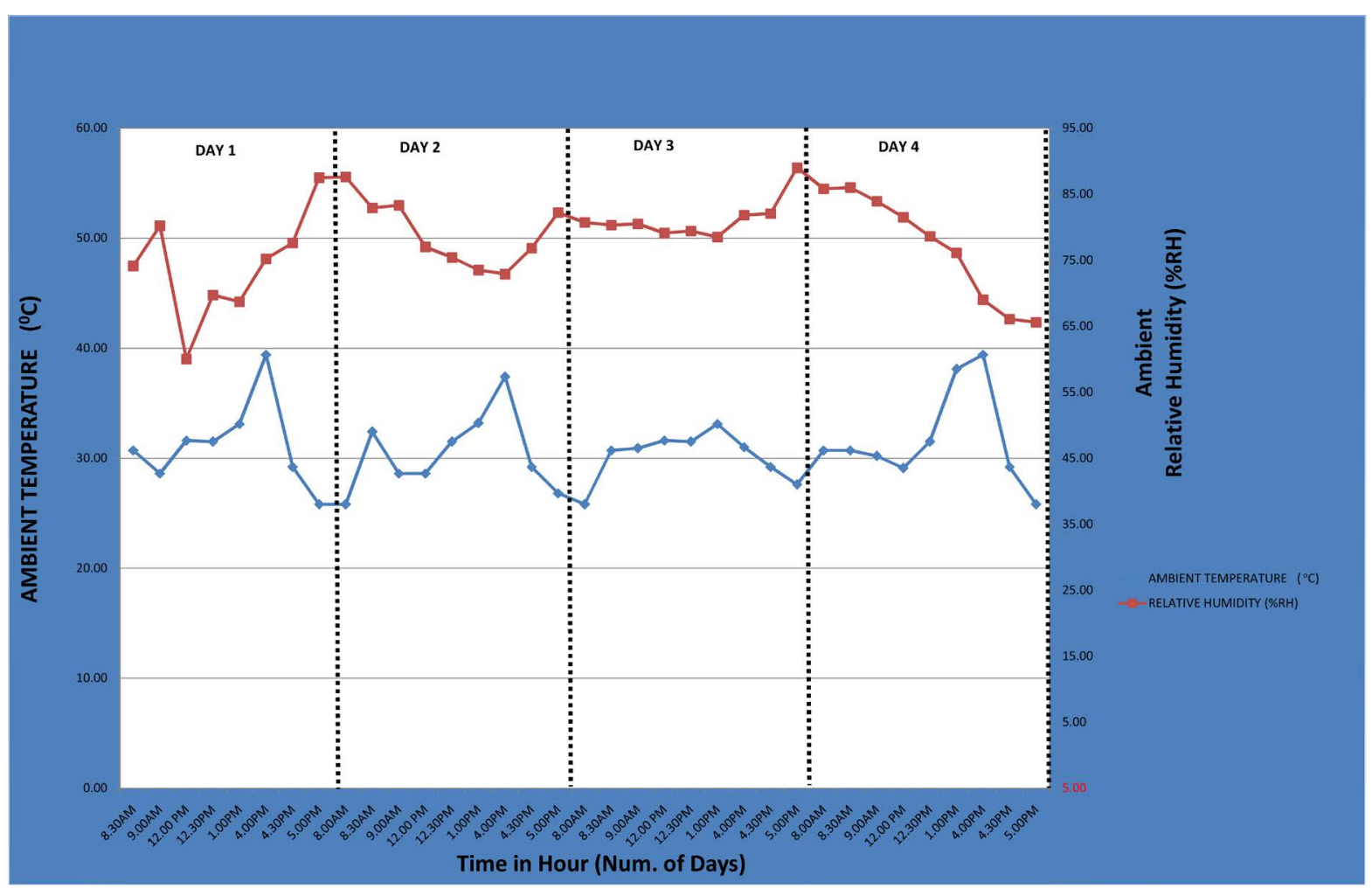

Figure 7. Temperatures \& relative humidity of ambient.

\section{Listen}

Read phonetically

Equation (8) is the relationship $\ln (-\ln \mathrm{MR})$ versus $t$, was the curve of the logarithmic equation, as shown in Figure 13 and Figure 14 for both type of drying. Henderson and Pabis equation can also be written by equation

$$
\ln \mathrm{MR}=-k t+\ln a
$$

From Equation (9), a plot of $\ln$ MR versus drying time gives a straight line with intercept $=\ln a$, and slope $=$ $k$. Graf MR versus $\ln t$, as shown in Figure 14 and Figure 15, obtained the value $k=0.154$ and the value of $a=$ 2.4278. A set of experiments was conducted to develop a drying model to simulate the drying curves of seaweed.

Drying models were fitted with the experimental data of drying in the form of changes in moisture content 


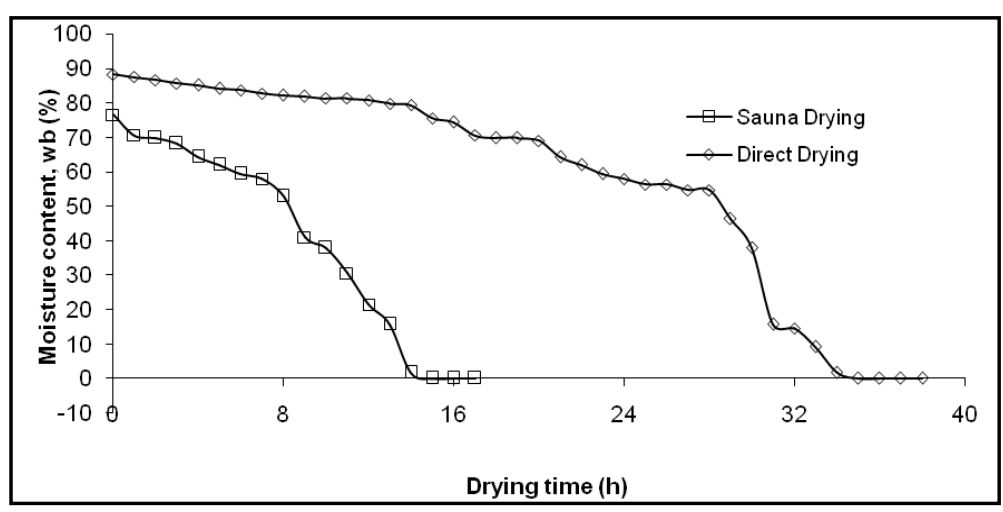

Figure 8. Drying curve: wet basis moisture content versus drying time.

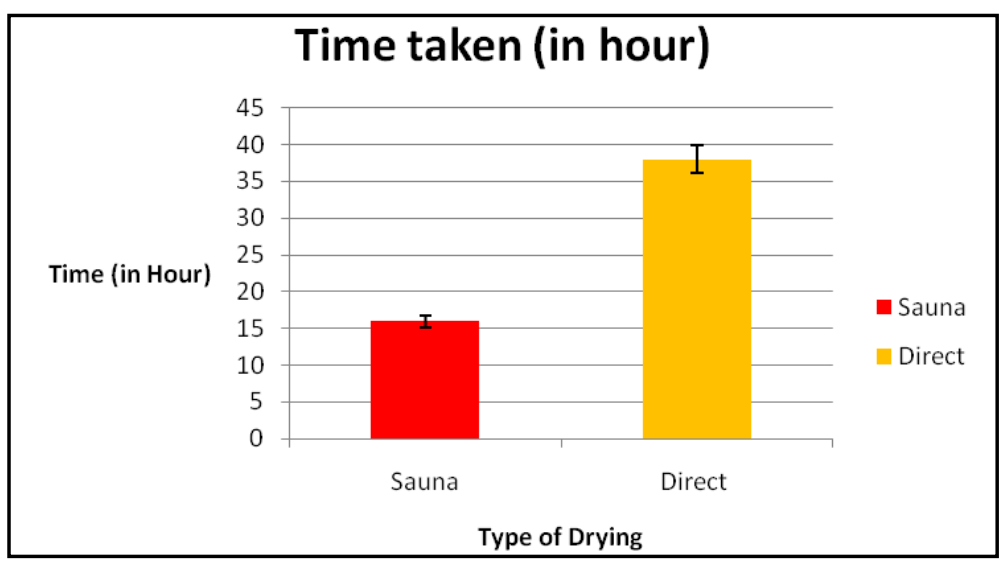

Figure 9. Saving time.

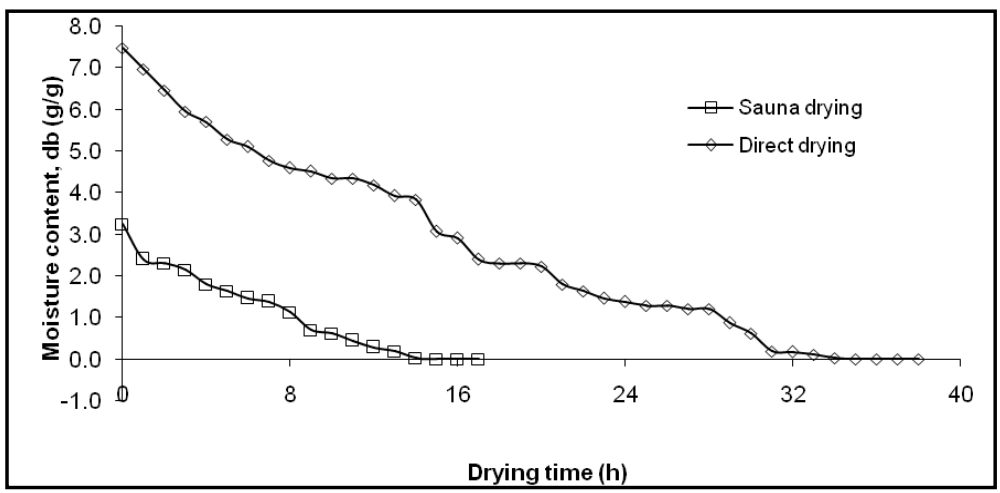

Figure 10. Drying curve: dry basis moisture content versus drying time.

versus drying time. In these drying models, changes in moisture content versus time calculated using Excel software. Fitting some of the drying model has been done with the experiment data, as shown in Figures 11-20. The values of $R^{2}$, MBE, RMSE and the parameters $a, n$ and the constant $k$ for the different models were listed in Tables 2-4. The highest value of $R^{2}$ and lowest value of MBE and RMSE indicated the goodness of the fit.

Results presented in Table 4 showed the model from sauna dried seaweed of the Page model has the highest value of $R^{2}(0.99027)$, as well as the lowest values of MBE (0.00044) and RMSE (0.03039), compared to Newton's model and Henderson and Pabis model. Accordingly, the Page model was selected as the suitable model to represent the thin layer drying behaviour of sauna dried seaweed. This is in accordance with Fudholi et al. [15]-[17] that Page model was shown to be a better fit to drying seaweed among other one-term exponential models thin layer drying models. 


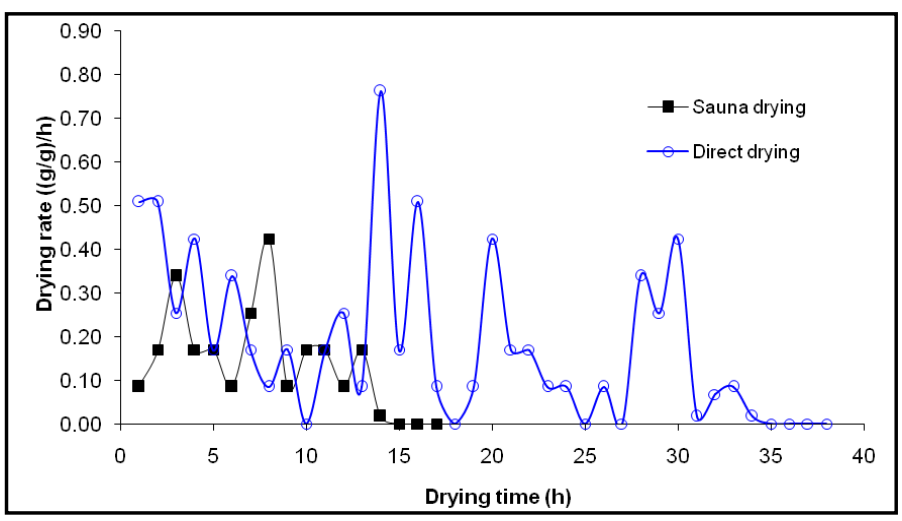

Figure 11. Drying curve: drying rate versus drying time.

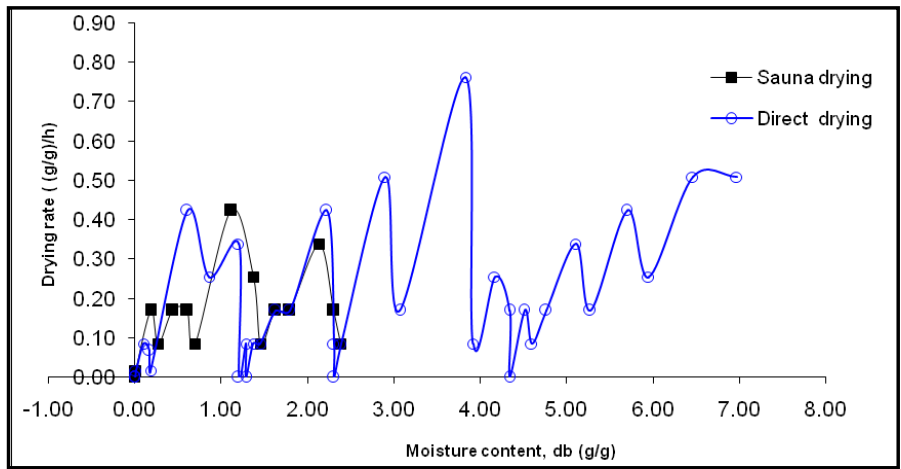

Figure 12. Drying curve: drying rate versus moisture content.

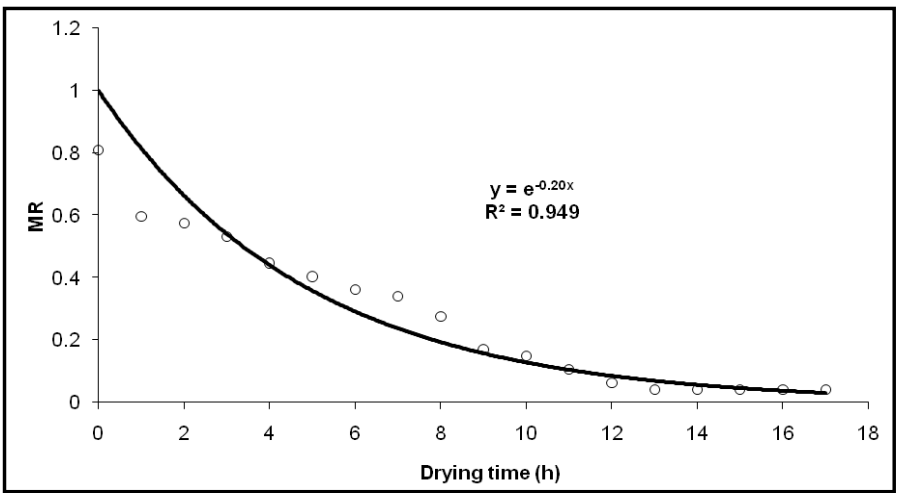

Figure 13. Plot of MR sauna versus drying time (Newton's model).

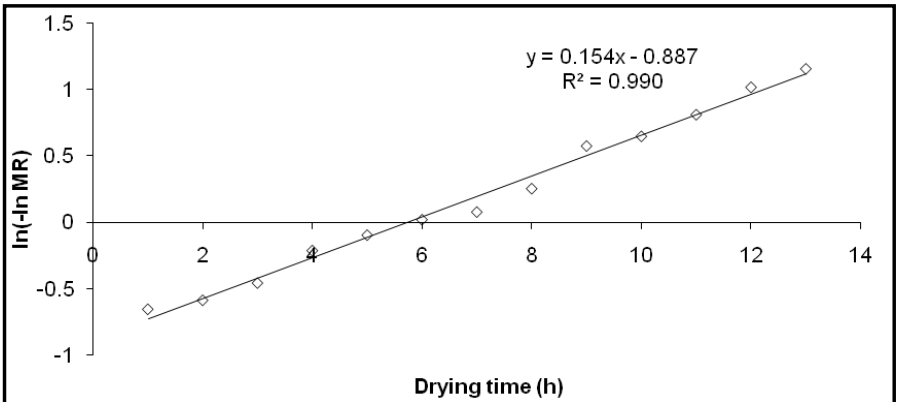

Figure 14. Plot of $\ln (-\ln \mathrm{MR})$ sauna versus drying time (Page model). 


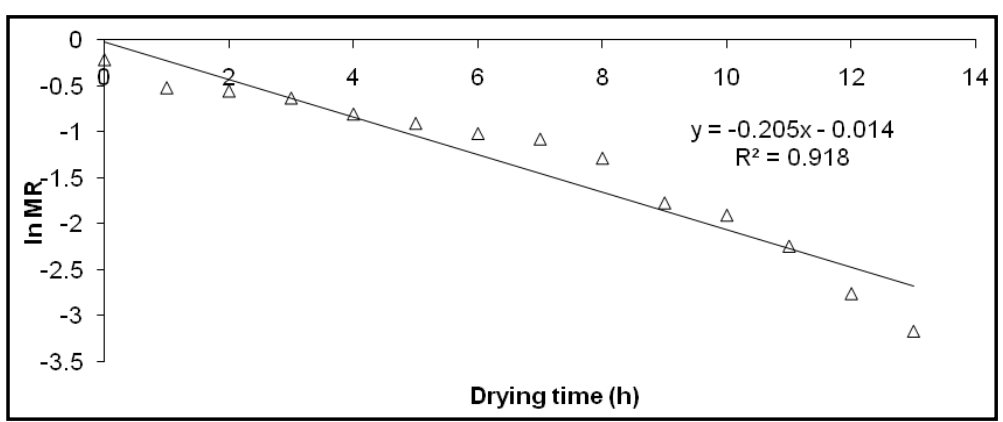

Figure 15. Plot of ln MR sauna versus drying time (Henderson and Pabis model).

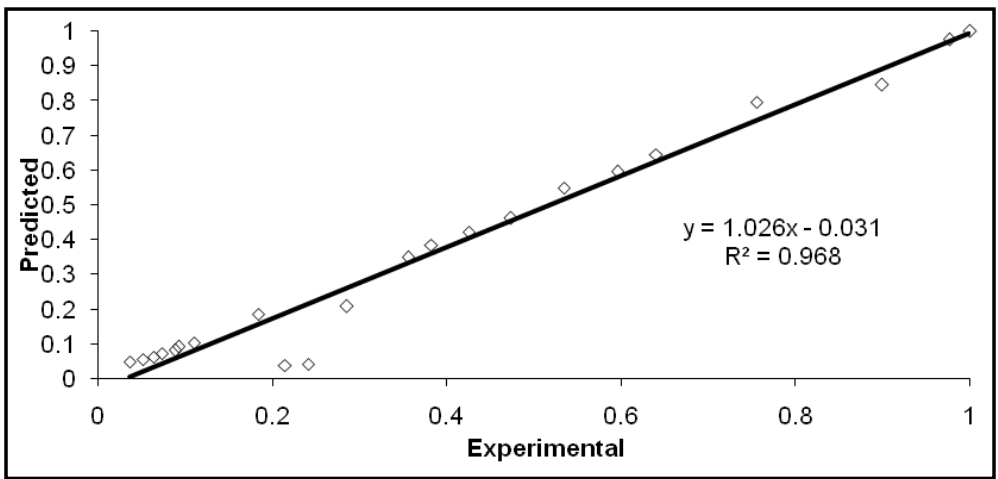

Figure 16. Comparison of experimental MR sauna with predicted MR sauna from Page model.

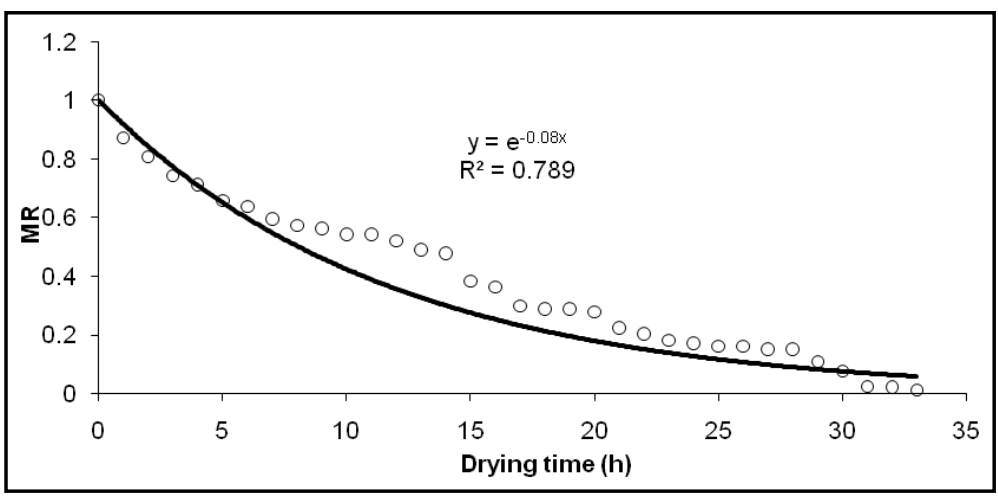

Figure 17. Plot of MR direct versus drying time (Newton's model).

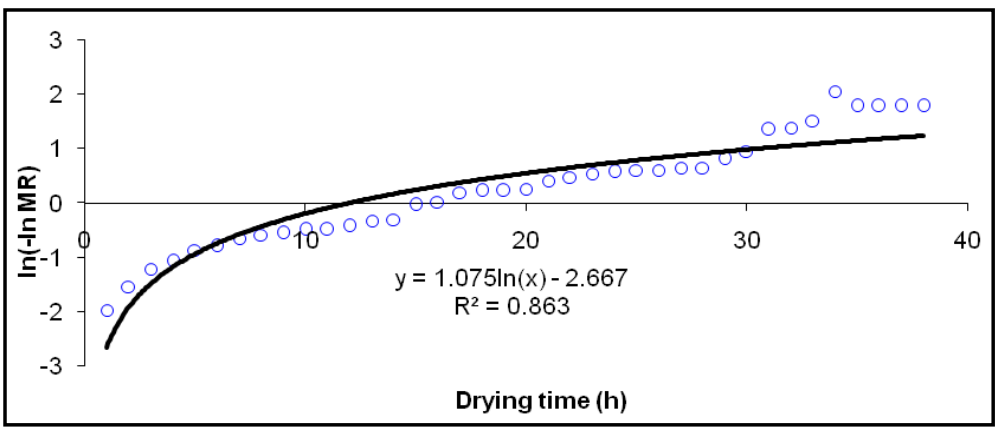

Figure 18. Plot of $\ln (-\ln M R)$ direct versus drying time (Page model). 


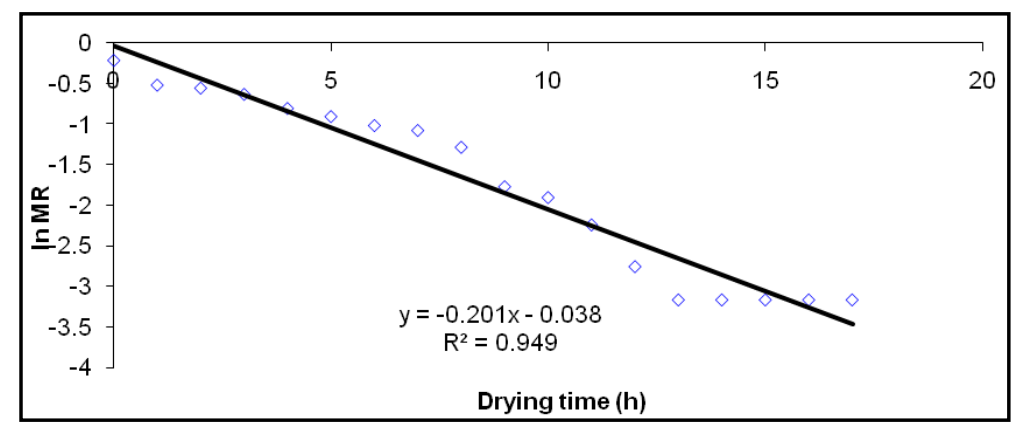

Figure 19. Plot of $\ln$ MR direct versus drying time (Henderson and Pabis model).

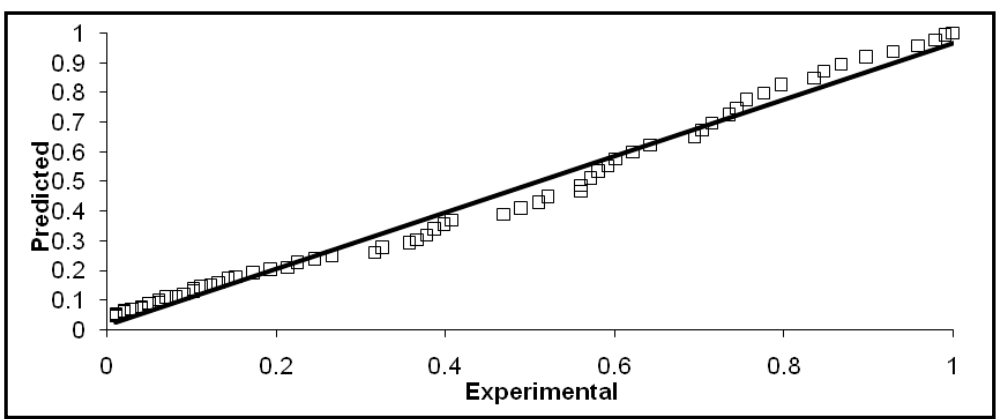

Figure 20. Comparison of experimental MR direct with predicted MR direct from Henderson and Pabis model.

Table 2. Constants value fitting of the sauna drying models.

\begin{tabular}{ccccccc}
\hline Model & $A$ & $k$ & $n$ & $R^{2}$ & MBE & RMSE \\
\hline Newton & & 0.205 & & 0.9490 & 0.00539 & 0.04274 \\
Page & 0.1546 & 0.8875 & & 0.9903 & 0.00044 & 0.03039 \\
Henderson and Pabis & & 0.2053 & 0.0146 & 0.9188 & 0.00013 & 0.01510 \\
\hline
\end{tabular}

Table 3. Constants value fitting of the direct drying models.

\begin{tabular}{ccccccc}
\hline Model & $a$ & $k$ & $n$ & $R^{2}$ & MBE & RMSE \\
\hline Newton & & 0.086 & & 0.7892 & 0.00729 & 0.08874 \\
Page & & 0.0947 & 0.2703 & 0.8234 & 0.00123 & 0.02610 \\
Henderson and Pabis & 0.9351 & 2.4071 & & 0.9108 & 0.00021 & 0.01339 \\
\hline
\end{tabular}

Table 4. Best fitting different drying technique models.

\begin{tabular}{cccccccc}
\hline Drying Type & $a$ & $k$ & $n$ & $R^{2}$ & MBE & RMSE & Best Model \\
\hline Sauna & 0.1546 & 0.8875 & & 0.9903 & 0.00044 & 0.03039 & Page \\
Direct & 0.9351 & 2.4071 & & 0.9108 & 0.00021 & 0.01339 & Henderson and Pabis
\end{tabular}

On the other hand, as far as the drying behavior of lemon grass is concerned, the Newton's model showed a better fit to the experimental data among other semi-theoretical models. Comparison of experimental MR with predicted MR from models drying. The distribution of experimental values in the vicinity of the straight line shows the expected value of Page model, as shown in Figure 14. 
The experimental results showed that sauna drying without auxiliary heating of $2500 \mathrm{~kg}$ of dry red seaweed required about $35 \%$ water content within $16 \mathrm{~h}$ ( 2 days of drying) to yield $281.5 \mathrm{~kg}$ of dried red seaweed. The summary of the experimental results and observations are given in Table 4.

\section{Conclusion}

The sauna drying technique was designed and imposed, constructed and tested for drying of seaweed. The seaweed moisture content was decreased around $50 \%$ in 2-day sauna. Kinetic curves of drying of seaweed were known to be used in this system. The non-linear regression procedure was used to fit three different drying models. The models were compared with experimental data of red seaweed being dried on the daily average of air temperature about $40^{\circ} \mathrm{C}$. The fit quality of the models was evaluated using the coefficient of determination $\left(R^{2}\right)$, Mean Bias Error (MBE) and Root Mean Square Error (RMSE). The highest values of $R^{2}(0.99027)$, the lowest MBE (0.00044) and RMSE (0.03039) indicated that the Page model was the best mathematical model to describe the drying behavior of sauna dried seaweed. The percentage of the saved time using this technique was calculated at $57.9 \%$ on the average solar radiation of about $500 \mathrm{~W} / \mathrm{m}^{2}$ and air flow rate of $0.056 \mathrm{~kg} / \mathrm{s}$.

\section{References}

[1] Ruslan, M.H., Fudholi, A., Othman, M.Y., et al. (2011) The Double Pass Solar Dryer for Drying Palm Oil Fronds. Proceedings of the 10th WSEAS International Conference on System Science and Simulation in Engineering, Penang, 2011, 143-149.

[2] Dissa, A.O., Bathiebo, D.J., Desmorieux, H., Coulibaly, O. and Koulidiati, J. (2011) Experimental Characterization and Modelling of Thin Layer Direct Solar Drying of Amelie and Brooks Mangoes. Energy, 36, 2517-2527.

http://dx.doi.org/10.1016/j.energy.2011.01.044

[3] Doymaz, I. (2010) Effect of Citric Acid and Blanching Pre-Treatments on Drying and Rehydration of Amasya Red Apples. Food and Bioproducts Processing, 88, 124-132. http://dx.doi.org/10.1016/j.fbp.2009.09.003

[4] Daun, X., Min, Z., Arun, S.M. and Shaojin, W. (2010) Microwave Freeze Drying of Sea Cucumber (Stichopus japonicus). Journal Food Engineering, 96, 491-497. http://dx.doi.org/10.1016/j.jfoodeng.2009.08.031

[5] Dissa, A.O., Desmoricux, H., Savadoge, P.W., Segda, B.G. and Koulidiati, J. (2010) Shinkage, Porosity and Density Behaviour during Convective Drying of Spirulina. Journal Food Engineering, 97, 410-418. http://dx.doi.org/10.1016/j.jfoodeng.2009.10.036

[6] Kilic, A. (2009) Low Temperature and High Velocity (LTHV) Application in Drying: Characteristics and Effects on the Fish Quality. Journal Food Engineering, 91, 173-182. http://dx.doi.org/10.1016/j.jfoodeng.2008.08.023

[7] Demirbas, A. (2010) Use of Algae as Biofuel Sources. Energy Conversion and Management, 51, 2738-2749. http://dx.doi.org/10.1016/j.enconman.2010.06.010

[8] Amin, S. (2009) Review on Biofuel Oil and Gas Production Processes from Microalgae. Energy Conversion and Management, 50, 1834-1840. http://dx.doi.org/10.1016/j.enconman.2009.03.001

[9] Ge, L., Peng, W. and Haijin, M. (2011) Study on Saccharification Techniques of Seaweed Wastes for the Transformation of Ethanol. Renewable Energy, 36, 84-89. http://dx.doi.org/10.1016/j.renene.2010.06.001

[10] Vergara-Fernandez, A., Vargas, G., Alarcon, N. and Velasco, A. (2007) Evaluation of Marine Laminaria Japonica as Source of Biogas in a Two-Stage Anaerobic Reactor System. Biomass and Bioenergy, 32, 338-344. http://dx.doi.org/10.1016/j.biombioe.2007.10.005

[11] Sopian, K., Othman, M.Y. and Zaidi, S.H. (2012) Advances in Solar Assisted Drying System for Marine and Agricultural Products. http://ases.conference-service.net/resources/252/2859/pdf/SOLAR 2012

[12] Fudholi, A., Sopian, K., Ruslan, M.H. Alghoul, M.A. and Sulaiman, M.Y. (2010) Review of Solar Dryers for Agricultural and Marine Products. Renewable and Sustainable Energy Reviews, 14, 1-30. http://dx.doi.org/10.1016/j.rser.2009.07.032

[13] Amer, B.M.A., Hossain, M.A. and Gottschalk, K. (2010) Design and Performance Evaluation of a New Hybrid Solar Dryer for Banana. Energy Conversion and Management, 51, 813-820. http://dx.doi.org/10.1016/j.enconman.2009.11.016

[14] Gupta, S., Cox, S. and Abu-Ghannam, N. (2011) Effect of Different Drying Temperatures on the Moisture and Phytochemical Constituents of Edible Irish Brown Seaweed. LWT-Food Science and Technology, 44, 1266-1272. http://dx.doi.org/10.1016/j.lwt.2010.12.022

[15] Fudholi, A., Othman, M.Y., Ruslan, M.H., Yahya, M., Zaharim, A. and Sopian, K. (2011) The Effects of Drying Air Temperature and Humidity on Drying Kinetics of Seaweed. In: Recent Research in Geography, Geology, Energy, En- 
vironment and Biomedicine, World Scientific and Engineering Academy and Society (WSEAS), Corfu, 129-133.

[16] Fudholi, A., Othman, M.Y., Ruslan, M.H., Yahya, M., Zaharim, A. and Sopian, K. (2011) Design and Testing of Solar Dryer for Drying Kinetics of Seaweed in Malaysia. In: Recent Research in Geography, Geology, Energy, Environment and Biomedicine, World Scientific and Engineering Academy and Society (WSEAS), Corfu, 119-124.

[17] Fudholi, A., Ruslan, M.H., Haw, L.C., Othman, S.M.M.Y., Zaharim, A. and Sopian, K. (2012) Mathematical Modeling of Brown Seaweed Drying Curves. Proceedings of the WSEAS International Conference on Applied Mathematics in Electrical and Computer Engineering, 207-211.

[18] Akpinar, E.K. (2010) Drying of Mint Leaves in a Solar Dryer and under Open Sun: Modelling, Performance Analyses. Energy Conversion and Management, 51, 2407-2418. http://dx.doi.org/10.1016/j.enconman.2010.05.005

[19] Akbulut, A. and Durmuş, A. (2010) Energy and Exergy Analyses of Thin Layer Drying of Mulberry in a Forced Solar Dryer. Energy, 35, 1754-1763. http://dx.doi.org/10.1016/j.energy.2009.12.028

[20] Meziane, S. (2011) Drying Kinetics of Olive Pomace in a Fluidized Bed Dryer. Energy Conversion and Management, 52, 1644-1649. http://dx.doi.org/10.1016/j.enconman.2010.10.027

[21] El-Sebaii, A.A., Aboul-Enein, S., Ramadan, M.R.I., Shalaby, S.M. and Moharram, B.M. (2011) Thermal Performance Investigation of Double Pass-Finned Plate Solar Air Heater. Applied Energy, 88, 1727-1739. http://dx.doi.org/10.1016/j.apenergy.2010.11.017

[22] Basri, D.F., Fudholi, A. and Ruslan, M.H. (2012) Drying Characteristics of the Borneo Canarium odontophyllum (Dabai) Fruit. The American Journal of Agricultural and Biological Science, 7, 347-356. http://dx.doi.org/10.3844/ajabssp.2012.347.356

[23] Othman, M.Y., Fudholi, A., Sopian, K., Ruslan, M.H. and Yahya, M. (2012) AnalisiskinetikpengeringanrumpailautGracilaria cangii menggunakansistempengeringsuria (Drying Kinetics Analysis of Seaweed Gracilaria cangii Using Solar Drying System). Sains Malaysiana, 41, 245-252.

[24] Tunde-Akintunde, T.Y. (2011) Mathematical Modeling of Sun and Solar Drying of Chilli Pepper. Renewable Energy, 36, 2139-2145. http://dx.doi.org/10.1016/j.renene.2011.01.017

[25] Azoubel, P.M., Baima, M.D.A.M., Amorim, M.D.R. and Oliveira, S.S.B. (2010) Effect of Ultrasound on Banana cv Pacovan Drying Kinetics. Journal of Food Engineering, 97, 194-198. http://dx.doi.org/10.1016/j.jfoodeng.2009.10.009

[26] Duc, L.A., Han, J.W. and Keum, D.H. (2011) Thin Layer Drying Characteristics of Rapeseed (Brassica napus L.). Journal of Stored Products Research, 47, 32-38. http://dx.doi.org/10.1016/j.jspr.2010.05.006

[27] Doymaz, I. (2005) Drying Behaviour of Green Beans. Journal of Food Engineering, 69, 161-165. http://dx.doi.org/10.1016/j.jfoodeng.2004.08.009

[28] Doymaz, I. (2005) Drying Characteristics and Kinetics of Okra. Journal of Food Engineering, 69, 275-279. http://dx.doi.org/10.1016/j.jfoodeng.2004.08.019

[29] Simal, S., Femenia, A., Garau, M.C. and Rosselló, C. (2005) Use of Exponential, Page's and Diffusion Models to Simulate the Drying Kinetics of Kiwi Fruit. Journal of Food Engineering, 66, 323-328. http://dx.doi.org/10.1016/j.jfoodeng.2004.03.025

[30] Ibrahim, M., Sopian, K. and Daud, W.R.W. (2009) Study of the Drying Kinetics of Lemon Grass. The American Journal of Applied Sciences, 6, 1070-1075. http://dx.doi.org/10.3844/ajassp.2009.1070.1075

[31] Van Gool, W. (1997) Enery Policy: Fairy Tales and Factualities. In: Soares, O.D.D., da Cruz, A.M., Pereira, G.C., Soares, I.M.R.T. and Reis, A.J.P.S., Eds., Innovation and Technology-Strategies and Policies, Kluwer Academic Publishers, Dordrecht, 93-105. http://dx.doi.org/10.1007/978-0-585-29606-7 6 


\section{Nomenclature}

A: drying constant;

exp: exponential;

$H$ : relative humidity $(\%)$;

$k$ : drying constant;

$M$ : moisture content air temperature $(\mathrm{J} / \mathrm{kg})$;

$M_{e}$ : equilibriummoisture content;

$M_{o}$ : initial moisture content;

MBE: Mean Bias Error;

$m$ : mass flow rate $(\mathrm{kg} / \mathrm{s})$;

$N$ : number of observations;

$n$ : drying constant;

$S$ : solar radiation $\left(\mathrm{W} / \mathrm{m}^{2}\right)$;

$R^{2}$ : coefficient of determination;

RMSE: Root Mean Square Error;

$T$ : temperature $\left({ }^{\circ} \mathrm{C}\right)$;

$t$ : drying time;

$v$ : volumetric airflow $\left(\mathrm{m}^{3} / \mathrm{s}\right)$;

$W$ : weight of water evaporated from the product;

$w$ : mass of wet materials.

\section{Subscripts}

exp: experimental;

pre: prediction. 
Scientific Research Publishing (SCIRP) is one of the largest Open Access journal publishers. It is currently publishing more than 200 open access, online, peer-reviewed journals covering a wide range of academic disciplines. SCIRP serves the worldwide academic communities and contributes to the progress and application of science with its publication.

Other selected journals from SCIRP are listed as below. Submit your manuscript to us via either submit@scirp.org or Online Submission Portal.
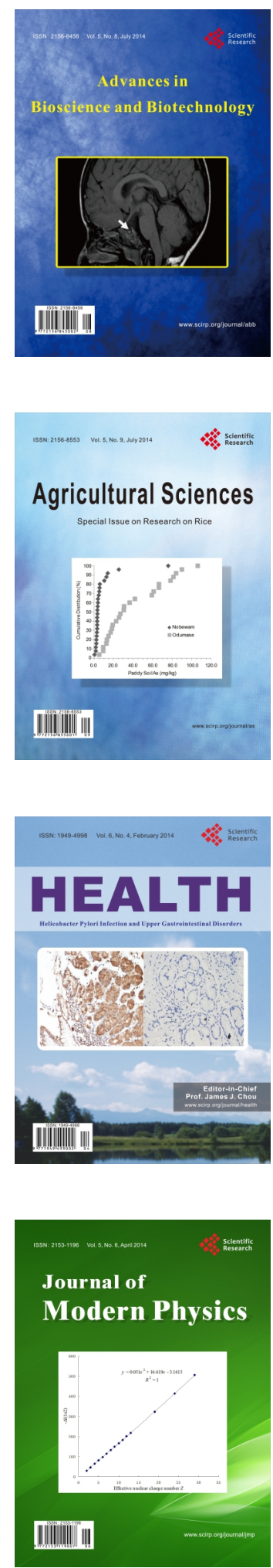
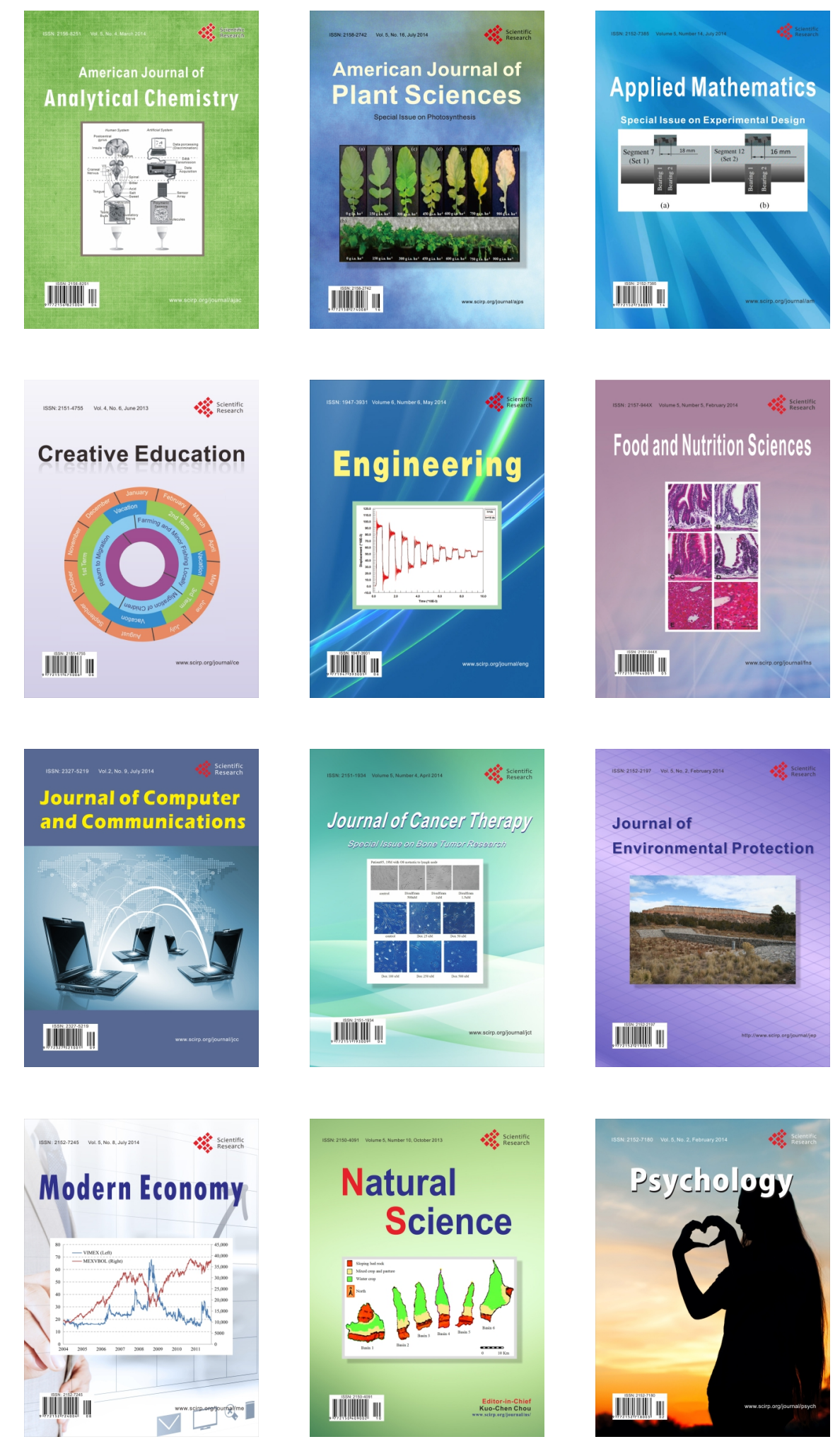